УДК 342.9

DOI https://doi.org/10.32837/pyuv.v1i4(29).389

\author{
Д. В. Крилов \\ orcid.org/0000-0001-8522-5433 \\ доктор економічних наук, докторант \\ Науково-дослідного інституту публічного права
}

\title{
ДОСВІД ОКРЕМИХ ЄВРОПЕЙСЬКИХ ДЕРЖАВ У СФЕРІ ЗДІЙСНЕННЯ ПУБЛІЧНО-СЕРВІСНОЇ ДІЯЛЬНОСТІ ОРГАНАМИ ДЕРЖАВНОЇ ВЛАДИ
}

Постановка проблеми. В основу реформування адміністративно-обслуговуючої функції органів державної влади розвинутих країн світу покладено принцип орієнтації на клієнта, створення демократизованої державної інституції, що поступово переходить від суто фіскальної функції до функції стимулювання господарської діяльності конкретного суб'єкта звернення й економічного розвитку країни загалом, а висока ефективність фінансових та правових систем базується на широкому використанні інформаційно-комунікаційних технологій, зокрема вільного доступу одних органів державної влади до інформаційних баз даних інших відповідних органів, а також підстави, умови та порядок отримання різного роду адміністративних послуг у будь-якій сфері [1]. Усе це потребує здійснення активних наукових пошуків, присвячених аналізу закордонного досвіду у сфері здійснення публічно-сервісної діяльності органами державної влади.

Стан дослідження. Питанню публічно-сервісної діяльності різних органів державної влади у своїх наукових дослідженнях неодноразово приділяли увагу багато науковців, зокрема: А.Б. Лис, Л.М. Щербаківська, Л.Л. Білик, I.I. Бригілевич, C.I. Ванько, В.А. Загайний, І.Б. Коліушко, О.В. Курінний, В.О. Стоян, В.П. Тимощук, О.В. Власенко, П.В. Ворона, М.О. Пухтинський, В.В. Юзефович, Н.Л. Астапова, Н.І. Ільчанінова, М.І. Мельник, В.Л. Федоренко, Я.О. Кагляк та багато інших. У своїх наукових працях учені звертали свою увагу на багато проблемних аспектів розвитку даного інституту, однак водночас малодослідженим залишився закордонний досвід щодо здійснення публічно-сервісної публічними адміністраціями, що є суттєвою прогалиною на теоретичному та практичному рівнях.

Мета статті - узагальнити досвід окремих європейських держав у сфері здійснення публічно-сервісної діяльності органами державної влади, визначити можливості його використання в Україні.

Виклад основного матеріалу. Перша європейська держава, досвіду якої ми приділимо увагу, - Франція. У 1992 р. Радою міністрів Франції була ухвалена «Хартія про надання державних послуг», у якій були представлені основні прин- ципи регулювання роботи французької державної служби на основі рівності, безпристрасності та наступництва, а також викладені нові принципи діяльності, як реакція на зміни в очікуваннях і вимогах населення, появу у споживачів нових потреб і запитів, необхідності прозорості та підзвітності, простоти і доступності [2, с. 45]. У Франції підвищення якості публічних послуг здійснюється шляхом регулярного оцінювання наявної практики їх надання та самої системи державного управління. Так, для оцінювання якості надання публічних послуг у цій країні було проведено кілька масштабних експериментів. Водночас виявлені чинники, що сприяють запровадженню нових підходів щодо питань якості. Одним із засобів підвищення якості надання послуг у Франції $є$ конкурс на визнання інноваційних ініціатив. Цей конкурс, починаючи із 2003 р., проводиться щорічно, сприяє демонстрації досягнень у діяльності 3 покращення якості прийому громадян, підвищення рівня управління якістю, діяльності зі створення партнерства. Крім того, основні принципи діяльності державних установ Франції, правила поведінки їх посадових осіб під час спілкування зі споживачами, а також зобов'язання 3 надання публічних послуг закріплені в «Хартії Маріанна», яка являє собою документ, аналогічний «Хартії громадян» у Великій Британії. Подальшим кроком щодо підвищення якості послуг у Франції було створення Комісії з питань якості державних послуг, яка $є$ незалежним органом і складається з високопоставлених службовців, до компетенції яких входить внесення пропозицій щодо формування політики уряду з питань якості. Цілями діяльності Комісії є: визначення стійких i реалістичних вимог для формування фактичних зобов'язань міністерств і служб; прагнення до дієвої (ефективної та результативної) системи державного управління; визначення місця споживача; формування культури проведення оцінювання; упровадження в адміністративну діяльність органів влади системи управління якістю [3; 4, c.187].

Ще одна європейська держава - Німеччина. У цій країні з метою отримання громадянином без ускладнень, швидко, за можливості, у рамках одного візиту адміністративної послуги, 
як і в багатьох європейських країнах, була розроблена модель єдиного офісу для громадян ("one-stop-shop"). На початку запровадження цієї новації у Федеративній Республіці Німеччина (далі - ФРН) активно вивчався досвід Нідерландів. Офіси для громадян у ФРН набагато повільніше утворювалися у великих містах, аніж у малих. Проте, наприклад, у Берліні нині вже 46 таких офісів. Ініціативи зі створення таких офісів у Німеччині віддано на розсуд муніципалітетів, оскільки ні спеціального законодавства, ні урядових (федеральних чи земельних) програм із цієї тематики не було. Отже, більшість міст запроваджували такі установи на власний розсуд, тому практика має багато особливостей. Універсами послуг (або «офіс для громадян» чи «бюро для громадян») є візитною карткою адміністрації (відображають їі імідж у громадськості), оскільки в них відбувається до 80\% контактів адміністрації iз приватними особами. Тому створювати універсам послуг рекомендується незалежно від розмірів громади, оскільки він є центральним місцем звернення громадян до адміністрації [5].

Кожен універсам послуг ухвалює рішення про спектр послуг, які ним будуть надаватися. У ФРН такий перелік включає послуги, які є часто запитуваними та надання яких не потребує тривалого опрацювання. Варто постійно переглядати ухвалений перелік для того, щоб інтегрувати в універсам послуг функції інших структур (наприклад, консультаційні пункти для пенсіонерів тощо). Зазвичай 80\% послуг становлять видача посвідчень особи та паспортів, реєстрація про прибуття (вибуття), перереєстрація, надання податкових карток. Універсами послуг в середніх і невеликих містах (від 25000 жителів), у яких немає служби реєстрації транспортних засобів, часто надають також і послуги, віднесені до компетенції цієї служби. Передача в офіс для громадян даної служби здійснюється на основі адміністративної угоди. Решта послуг (20\%), що надаються: загальні довідки та надання консультацій; видача формулярів заявок інших відомств; засвідчення документів; бюро знахідок (прийняття загублених речей та їх продаж через аукціони), продаж квитків та мішків для сміття; інформація для туристів та гостей; надання інформаційних матеріалів інших установ, продаж карт міст, книжок, рекламної продукції тощо [5].

Підсумовуючи досвід Німеччини, Н.В. Шамрай виділяє такі важливі аспекти, які вбачаються доцільними для впровадження в Україні: 1. Наявність Єдиного стандарту якості для таких сфер: асортимент / вибір завдань; обробка документації одним органом; організація структури; години прийому для громадян; персонал; інформаційна та комунікаційна техніка; облаштування робочих приміщень. 2. Забезпечення таких критеріїв якості: сервіс з одних рук; широкий асортимент послуг (80\% усіх комунальних адміністративних послуг, які громадяни потребують протягом року, надаються універсамами послуг); зручне для громадян транспортне сполучення. 3. Повний асортимент завдань: виконання в повному обсязі функцій $з$ оформлення документів, паспортів, а також реєстрації громадян; надання повного асортименту послуг із документального оформлення транспортних засобів (від реєстрації до виводу 3 експлуатації); видача водійських посвідчень (зокрема, міжнародного зразка); інші «швидкі» послуги в соціальній сфері, сфері громадського порядку, реєстрації актів цивільного стану; широкий асортимент інформаційних і консультаційних послуг. 4. Ефективний підхід до організації структури. Чим більшою є кількість мешканців комуни, тим більшою є доцільна кількість децентралізованих універсамів послуг (комунна спілка з адміністративного менеджменту). 5. Ротація діловодів між універсамами послуг залежно від потреб (черги, сезонність послуг). 6. Персонал: відбір та підготовка персоналу; формалізована процедура вибору, після якої здійснюється трирічна підготовка за напрямом «Фаховий адміністративний працівник». Потім відбувається призначення на вільну посаду у службах обслуговування громадян; підвищення кваліфікації, план тренінгів не менше трьох місяців, обрані працівники виконують роль наставників. Тренінги в інших структурах у контексті набуття соціальних компетенций. Внутрішні та зовнішні тренінги в контексті фахової роботи. Наприклад, практика в іншому галузевому органі. 7. Облаштування приміщень: центральне та зручне розташування в адміністративній будівлі; зручний доступ для громадян з обмеженими фізичними можливостями; світлі та приємні для відвідування великі приміщення; приємна атмосфера (освітленість, вентиляція, захист від шуму, рослини, картина тощо); приміщення для підготовчої роботи; зручна та велика зона очікування з безкоштовними інформаційними матеріалами; кімната психологічної розгрузки для діловодів; ігрові куточки для дітей. 8. Бюджет офісів 3 обслуговування громадян $[6 ; 7 ; 8$, с. 80-81].

На особливу увагу заслуговує досвід Польської Республіки, адже ця країна першою з усіх посткомуністичних держав стала на шлях європейської інтеграції. У Польщі формування єдиної централізованої системи надання публічних послуг населенню пов'язане з адміністративно-територіальною реформою, яка проводилася у країні у 2000-х рр., відповідно до якої організацію надання публічних послуг було покладено на органи територіального самоврядування. Територіальне самоврядування є важливою частиною публічної адміністрації в Республіці Польща. Воно 
поділяється на місцеве (рівень гміни та повіту) i регіональне (рівень воєводства), які не мають ієрархічної залежності. Варто зазначити діалектичну єдність діяльності в Польщі урядової та самоврядної адміністрацій. Якщо для органів державної виконавчої влади характерне вертикальне підпорядкування, то органи територіального самоврядування всіх рівнів є незалежними як між собою, так і від органів державної виконавчої влади. Але ця незалежність поєднується з необхідністю спільно вирішувати проблеми територій, що неминуче веде до співпраці. Основним завданням органів територіального самоврядування є організація надання публічних послуг для мешканців. Ці послуги поділяються на комунальні (енергія, водопостачання та каналізація, транспорт, утримання доріг і зелених насаджень тощо), соціальні (навчання, охорона здоров'я, соціальна допомога, безпека, культура, питання ринку праці тощо) й адміністративні. Органи самоврядування повинні організувати надання послуг мешканцям, але не зобов'язані їх самостійно надавати. Зазвичай для цього укладаються контракти із суб'єктами господарювання чи неурядовими організаціями [9, с. $101 ; 10]$.

У Польщі також запроваджено ідею єдиного офісу для громадян - WOM, так було заплановано в усіх районах Варшави для забезпечення мешканцям міста належної якості послуг і прискорення адміністративних процедур. Зазначені відділи створено як установи, де кожен мешканець Варшави має можливість легко вирішити свої справи в офіційній сфері, зокрема питання обміну ID-карток, реєстрації транспортного засобу, отримання ліцензії тощо. Відділи WOM пропонують споживачам надійні, кваліфіковані та швидкі послуги: якщо раніше споживачам потрібно було відвідати декілька кабінетів у приміщенні установи, то зі створенням відділів адміністративні процедури було значно спрощено $[11 ; 12]$.

Варто навести думку В.В. Юзефовича і Н.Л. Астапової, які у своєму науковому дослідженні обгрунтували, що в контексті вдосконалення здійснення органами публічної адміністрації публічно-сервісної діяльності найбільш доцільно використовувати такий досвід Польської Республіки [13, с. 132]:

- удосконалення законодавчої бази у сфері публічно-сервісної діяльності;

- створення альтернативних систем надання послуг;

- підготовка керівників і фахівців сфери державного управління, регіонального управління та місцевого самоврядування зі здійснення якісно орієнтованого надання послуг;

- запровадження новітніх інформаційних технологій із метою більш повного і якісного задоволення адміністративних потреб громадян та надання послуг державними органами з використанням електронних мереж;

- моніторинг діяльності службовців державної служби та служби в органах місцевого самоврядування, оцінки показників кінцевих результатів [13, с. 132].

Наступна посткомуністична країна досвіду, якої ми приділимо увагу, - Естонія. Ця держава першою з республік колишнього Радянського Союзу подолала трансформаційний спад і в 1994 р. перейшла до економічного зростання. Естонців завжди відрізняв твердий індивідуалістичний настрій, незалежність мислення, що сприяло становленню раціонального підприємницького капіталізму в державі. Ключовими складовими частинами перетворень були глибока мікроекономічна лібералізація, радикальна валютна реформа і грошова приватизація. Здійснені урядом заходи з лібералізації цін і укладення низки угод з Свропейським Союзом дозволили республіці отримати право користуватися свободою торгівлі нарівні з європейськими країнами. Усе це дозволило не лише швидко подолати дефіцит товарів i послуг (характерний для соціалізму), а й перетворити Естонію на державу з найменшим рівнем корупції серед усіх пострадянських республік [14; 8, с. 82-83]. Пріоритетним напрямом у ліквідуванні бюрократичної паперової тяганини, яка вимагала від громадян спілкування 3 великою кількістю відомств, стало впровадження державного проєкту «Електронна Естонія». Це потребувало уніфікації численних реєстрів і формування централізованої інформаційної бази, упровадження принципу "єдиного вікна», за якого всі послуги населенню надавалися за допомогою автоматизованих центрів обслуговування [8, с. 82-83]. В Естонії приділяється значна увага послугам для пересічних громадян. Серед них дослідники виділяють такі: Е-поліція - отримання через електронну пошту квитанцій на оплату штрафів за порушення правил дорожнього руху; Е-школа електронний щоденник, який дозволяє налагодити зв’язок шкільної адміністрації з батьками учнів, включає розклад занять, отримані учнями оцінки, а також домашні завдання; Е-депозитарій - централізований реєстр усіх акціонерних товариств у країні та цінних паперів; Е-пенсія - електронна система обслуговування фізичних осіб із питань отримання пенсій, вибору пенсійних фондів, обмін звітністю тощо; ID-білет - сервіс продажу квитків на муніципальний транспорт, відвідування закладів культури тощо [15].

Загалом, аналіз естонського досвіду дозволяє говорити про низку корисних результатів надання адміністративних послуг в електронному вигляді. Сюди можна віднести вільний доступ споживачів до послуг у будь-який час із будь-якого місця, де $є$ доступ до Інтернету. Особливо це корисно для осіб, 
які за об'єктивних причин не мають можливості особисто відвідати відповідний орган публічного управління за отриманням послуги [15; 16; с. 133]. Не останнє місце в позитивних результатах електронного врядування посідає значна економія фінансів і часу. Збирання всієї необхідної інформації в одній базі створює умови для зручності сервісної діяльності. Особливо актуальним для України можна назвати безпеку електронного документообігу, зведення до мінімуму технічних помилок, створення умов для більшої прозорості та зменшення корупціогенної складової частини під час надання адміністративних послуг. У свою чергу, це дозволяє створити позитивний імідж органів публічного управління та налагодити їх взаємодію iз широкою громадськістю. Загалом естонський досвід залучення новітніх технологій у модернізації механізму надання адміністративних послуг потребує більш ретельного аналізу з метою його використання й адаптації до українських реалій, оскільки беззаперечні його результативність і відносна економічність [15; 16; с. 133].

Висновки. Завершуючи наукове дослідження, варто узагальнити, що світова практика налічуе досить багато позитивних прикладів здійснення органами публічної адміністрації публічно-сервісної діяльності. Це стосується як держав - світових лідерів (Німеччина, Франція), так і країн посткомуністичного простору (Польща, Литва, Естонія). Отже, дуже важливо, щоб Україна продовжувала свій курс на європейську інтеграцію та використовували вже існуючі напрацювання інших країн. Тож, на нашу думку, з метою вдосконалення здійснення органами публічної адміністрації публічно-сервісної діяльності в Україні важливий для запозичення такий закордонний досвід: окрему увагу варто приділити професійній підготовці державних службовців, зокрема посилити їхю психологічну готовність до здійснення відповідної діяльності; треба суттєво покращити матеріально-технічне забезпечення публічних адміністрацій, оскільки сьогодні в Україні наявна ситуація відмов програмного забезпечення, що перешкоджає якісному та швидкому наданню відповідних послуг; необхідне створення загальнодержавної єдиної інформаційної бази.

\section{Jimepamypa}

1. Миронюк Р.В. Окремі напрями впровадження зарубіжного досвіду надання адміністративних послуг податковими органами. Науковий вісник Дніпропетровського державного університету внутрішніх справ. 2014 . № 4. С. $179-188$.

2. Лис А.Б. Світовий досвід надання послуг населенню державними і самоврядними органами влади. Аспекти публічного управління. 2015. № 9. C. $43-50$.

3. Жерліцин Д.К. Деякі аспекти практики надання якісних публічних послуг органами влади у США, Великій Британії, Канаді, Польщі, Японії,
Швеції, Франції. URL: http://82-117-235-189.gpon. sta.kh.velton.ua/e-book/db/2010-2/doc/5/03.pdf.

4. Циганов О.Г. Зарубіжний досвід ініціатив органів публічної влади щодо удосконалення системи надання адміністративних послуг. Visegrad Journal on Human Rights (Словацька Республіка). 2018. C. 185-190.

5. Драган I.O. Організація надання публічних послуг населенню органами влади : зарубіжні практики. Державне управління: удосконалення та розвиток. 2014. № 4. URL: http://nbuv.gov.ua/UJRN/ Duur 201443.

6. Офіційний сайт міста Саарбрюккен, Німеччина. URL: http://www.Saarbruecken.de/rathaus.

7. Офіційний сайт міста Tpip, Німеччина. URL: http://www.trier.de/Startseite/.

8. Шамрай Н.В. Організація надання публічних послуг у містах з районним поділом : дис. ... канд. наук з держ. упр.: 25.00.04. Київ, 2017. 279 с.

9. Зарубіжний досвід організації та роботи місцевої влади : монографія / О.В. Власенко та ін. Полтава : Полтав. НТУ, 2009. 288 с.

10. Тихонова Д.С. Зарубіжний досвід надання адміністративних послуг органами публічної влади та можливості його використання в Україні. Право i Безпека. 2014. № 4. С. 70-75.

11. Витяг з матеріалу, підготовленого експертом ЦППР Олексієм Курінним. URL: http://www.ekmair. ukma.kiev.ua/ bitstream/123456789/1544/1/centry_ nadannia poslug 2011.pdf.

12. Топча А.О. Організація надання адміністративних послуг у зарубіжних країнах: досвід для України. Часопис Київського університету права. 2015. № 1. C. $350-353$.

13. Юзефович В.В., Астапова Н.Л. Досвід зарубіжних країн у сфері надання адміністративних послуг: організаційний аспект. Право та державне управління. 2016. № 3. С. 130-136.

14. Васильєва Н.В. Досвід Естонії у наданні електронних послуг населенню. Державне управління: удосконалення та розвиток : електронне наукове фахове видання. URL: http://www.dy.nayka.com.ua/?op=1 $\& \mathrm{z}=650$.

15. Туркова О.К. Надання електронних послуг в Естонії: адміністративно+правовий аспект. Науковий вісник Міжнародного гуманітарного університету. Серія «Юриспруденція». 2016. Вип. 20. С. 60-62.

16. Ільчанінова H.I. Перспективи впровадження зарубіжного досвіду формування механізму надання адміністративних послуг в Україні. Інвестицї̈: практика та досвід. 2018. № 10. С. 130-134.

\section{Анотація}

Крилов Д. В. Досвід окремих європейських держав у сфері здійснення публічно-сервісної діяльності органами державної влади. - Стаття.

Мета статті - узагальнення досвіду окремих європейських держав у сфері здійснення публічно-сервісної діяльності органами державної влади, з'ясування можливості його використання в Україні. У статті, на основі аналізу наукових поглядів учених, узагальнено закордонний досвід у сфері здійснення публічно-сервісної діяльності органами державної влади, визначено можливості його використання в Україні. Обгрунтовано необхідність підвищення уваги законодавця до професійної підготовки державних службовців, зокрема зазначено, що варто посилити їхню психологічну готовність до здійснення відповідної діяльності. Наголошено на важливості суттєвого покращення матеріально-технічного 
забезпечення публічних адміністрацій. Визначено, що в Польщі формування єдиної централізованої системи надання публічних послуг населенню пов'язане з адміністративно-територіальною реформою, яка проводилася у країні у 2000-х роках, відповідно до якої організацію надання публічних послуг було покладено на органи територіального самоврядування. Територіальне самоврядування $є$ важливою частиною публічної адміністрації в Республіці Польща. 3'ясовано, що в Польщі також реалізовано ідею єдиного офісу для громадян - WOM, так було заплановано в усіх районах Варшави для забезпечення мешканцям міста належної якості послуг та прискорення адміністративних процедур. Зазначені відділи створено як установи, де кожен мешканець Варшави має можливість легко вирішити свої справи в офіційній сфері, зокрема питання обміну ID-карток, реєстрації транспортного засобу, отримання ліцензії тощо. Наголошено, що аналіз естонського досвіду дозволяє говорити про низку корисних результатів надання адміністративних послуг в електронному вигляді. Сюди передусім можна віднести вільний доступ споживачів до послуг у будьякий час із будь-якого місця, де є доступ до Інтернету. Зроблено висновок, що особливо актуальна для України безпека електронного документообігу, зведення до мінімуму технічних помилок, створення умов для більшої прозорості та зменшення корупціогенної складової частини під час надання адміністративних послуг. У свою чергу, це дозволяє створити позитивний імідж органів публічного управління та налагодити їх взаємодію із широкою громадськістю.

Ключові слова: зарубіжний досвід, публічно-сервісна діяльність, органи державної влади, законодавство.

\section{Summary}

Krylov D. V. The experience of European states in public service activities by the state bodies. - Article.

The purpose of the article is to summarize the experience of individual European states in the field of public service activities by public authorities, and to determine the possibilities of its use in Ukraine.
The article, based on the analysis of scientific views of scientists, generalizes foreign experience in the field of public-service bodies of state power and identifies the possibility of its use in Ukraine. The necessity of increasing the attention of the legislator to the professional training of civil servants is substantiated, in particular, it is noted that their psychological readiness for carrying out the corresponding activity should be enhanced. The importance of significantly improving the logistics of public administrations is emphasized. It has been determined that the formation of a single centralized public service delivery system in Poland is linked to the administrative-territorial reform that took place in the country in the $2000^{\mathrm{s}}$, whereby the organization of public service provision was entrusted to territorial self-government bodies. Territorial selfgovernment is an important part of public administration in the Republic of Poland. It is revealed that Poland has also introduced the idea of a single office for citizens WOM, so it was planned in all parts of Warsaw to provide the city residents with good quality services and speed up administrative procedures. These departments are established as institutions where every resident of Warsaw has the opportunity to easily solve their business in the official field, in particular, the issue of exchange of ID-cards, registration of the vehicle, obtaining a license, etc. It is emphasized that the analysis of the Estonian experience allows us to speak about a number of useful results of the provision of administrative services in electronic form. These include, first of all, free access of consumers to services at any time from any place where there is access to the Internet. It is concluded that electronic document circulation, minimizing technical errors, creating conditions for greater transparency and reducing the corruption component in the provision of administrative services are particularly relevant for Ukraine. This, in turn, helps to create a positive image of public administration bodies and to establish their interaction with the general public.

Key words: foreign experience, public service activity, public authorities, legislation. 